\title{
ANTESEDEN KINERJA KARYAWAN PT. BANK MALUKU DAN MALUKU UTARA CABANG AMBON
}

\section{WYLDA OLIVIA KOWEY*}

Jurusan Administrasi Bisnis, Politeknik Negeri Ambon, Jalan Ir. M. Putuhena, Wailela, Ambon

\begin{abstract}
ABSTRAK: Penelitian ini bertujuan untuk menganalisis faktor-faktor yang menjadi determinan kinerja karyawan PT Bank Maluku dan Maluku Utara Cabang Ambon. Data dikumpulkan menggunakan kuesioner yang dibagikan kepada 103 orang pegawai PT Bank Maluku dan Maluku Utara Cabang Ambon. Data yang dikumpulkan selanjutnya dianalisis menggunakan analisis deskriptif dan analisis jalur (path analysis). Hasilnya menunjukan kompensasi, motivasi kerja, lingkungan kerja memiliki pengaruh positif dan signifikan baik langsung maupun tidak langsung terhadap kepuasan kerja dan kinerja pegawai. Begitu juga kepuasan kerja pada kinerja pegawai. Selanjutnya, hasil penelitian ini merekomendasikan agar dalam upaya untuk membentuk kepuasan kerja dan kinerja pegawai, disarankan agar pihak manajemen PT Bank Maluku Maluku Utara hendaknya senantiasa memberi perhatian pada pemberian kompensasi, baik finansial maupun non finansial, pemberian motivasi kerja, baik yang berisfat intrinsik maupun ekstrinsik, serta penciptaan lingkunga kerja internal yang baik dan kondusif.
\end{abstract}

\begin{abstract}
This study aims to analyze the factors that become determinants of employee performance of PT Bank Maluku and North Maluku Ambon Branch. Data are collected using questionnaires distributed to 103 employees of PT Bank Maluku and North Maluku Ambon Branch. The data collected is further processed using descriptive analysis and path analysis. The results show that compensation, work motivation, and work environment have positive and significant influence both directly and indirectly on job satisfaction and employee performance. Job satisfaction has a positive and significant impact on employee performance. Furthermore, the results of this study recommend that in order to establish job satisfaction and performance of employees, it is suggested that the management of PT Bank Maluku North Maluku must always pay attention to the compensation, both financial and non-financial, motivation of work, both intrinsic as well as extrinsic, and the creation of a good and conducive internal working environment.
\end{abstract}

Keywords: Work motivation, work environment, compensation, job satisfaction, employee performance

*Surel Korespondensi Penulis: olivia_nikijuluw@yahoo.co.id 


\section{PENDAHULUAN}

Keberadaan sumber daya manusia di perusahaan memegang peranan penting. Tenaga kerja memiliki potensi yang besar untuk menjalankan aktivitas perusahaan. Potensi setiap sumber daya manusia yang ada dalam perusahaan harus dapat dimanfaatkan dengan sebaik-baiknya sehingga mampu memberikan output optimal. Tercapainya tujuan perusahaan tidak hanya tergantung pada peralatan modern, sarana dan prasarana yang lengkap, tetapi justru lebih tergantung pada manusia yang melaksanakan pekerjaan tersebut. Keberhasilan suatu organisasi sangat dipengaruhi oleh kinerja individu karyawannya. Setiap organisasi perusahaan akan selalu berusaha untuk meningkatkan kinerja karyawan, agar tujuan perusahaan dapat tercapai.

Dalam meningkatkan kinerja karyawannya perusahaan menempuh beberapa cara misalnya melalui pendidikan, pelatihan, pemberian kompensasi yang layak, menciptakan lingkungan kerja yang kondusif dan pemberian motivasi. Melalui proses-proses tersebut, karyawan diharapkan akan lebih memaksimalkan tanggung jawab atas pekerjaan mereka karena para karyawan telah dibekali terkait dengan implementasi pekerjaan mereka. Terdapat banyak faktor yang memengaruhi prestasi kerja pegawai di antaranya pemberian kompensasi dan motivasi (Arma \& Syariati, 2015; Efendi, 2018; Awaluddin, 2016; Nurfarhana \& Said, 2017; Parmitasari, 2011; Suhartini \& Anisa, 2017; Syariati \& Syariati, 2012).

Prestasi kerja akan dapat dicapai jika didahului dengan perbuatan yaitu melaksanakan tugas yang dibebankan. Untuk menjamin tercapainya keselarasan tujuan, pimpinan organisasi memberikan kompensasi, yang merupakan bagian dari hubungan timbal balik antara organisasi dengan sumber daya manusia. Karyawan akan lebih termotivasi melakukan tanggung jawab atas pekerjaan mereka apabila perusahaan mengerti dan memerhatikan kebutuhan mereka, karena pada dasarnya mereka bekerja untuk mendapatkan uang berbentuk gaji.

Kompensasi adalah semua pendapatan yang berbentuk uang, barang langsung atau tidak langsung yang diterima karyawan sebagai imbalan atas jasa yang diberikan kepada perusahaan (Hasibuan, 2002). Kompensasi adalah penghargaan atau ganjaran pada para pekerja yang telah memberikan kontribusi dalam mewujudkan tujuannya, melalui kegiatan yang disebut bekerja (Nawawi, 2001). Kompensasi juga merupakan penghargaan yang diberikan karyawan baik langsung maupun tidak langsung, finansial maupun non finansial yang adil kepada karyawan atas sumbangan mereka dalam mencapai tujuan organisasi, sehingga pemberian kompensasi sangat dibutuhkan oleh perusahaan manapun guna meningkatkan kinerja karyawannya. Tujuan pemberian kompensasi antara lain adalah sebagai ikatan kerja sama, kepuasan kerja, pengadaan efektif, motivasi, stabilitas karyawan, disiplin, serta pengaruh serikat buruh dan pemerintah.

Tidak hanya faktor pemberian kompensasi saja yang perlu diperhatikan oleh perusahaan guna menigkatkan kinerja karyawan. Perusahaan juga harus memerhatikan faktor motivasi kerja pegawainya. Pegawai dapat melaksanakan tugasnya, antara lain ditentukan oleh motivasi yang mendorong pegawai itu 
bekerja dengan tekun, serta disiplin yang diterapkan sehingga dapat tercapai tujuan perusahaan. Setiap pegawai belum tentu bersedia mengerahkan kemampuan kerja yang dimilikinya secara optimal, sehingga masih diperlukan adanya pendorong agar seseorang mau menggunakan seluruh potensinya untuk bekerja.

Vroom dan Dessler (1997) dalam Arrizal (1999) mengatakan orang-orang biasanya termotivasi atau terdorong untuk bekerja pada suatu jabatan tertentu yang mereka rasa akan memeroleh imbalan. Berdasarkan hukum motivasi kerja, untuk memotivasi kerja seorang pegawai diperlukan dua syarat mutlak yaitu kemampuan kerja dan kemauan kerja. Motivasi diartikan sebagai faktorfaktor yang mengarahkan dan mendorong perilaku atau keinginan seseorang untuk melakukan suatu kegiatan yang dinyatakan dalam bentuk usaha yang keras atau lemah (Hariandja, 2002).

Pemahaman terhadap motivasi karyawan sangat penting kaitannya dengan pencapaian tujuan, yaitu produktivitas dan efesiensi. Terpenuhinya kompensasi dan pemberian motivasi yang baik tentu saja akan meningkatkan produktivitas serta kinerja karyawan. Karena itu salah satu cara terbaik untuk meningkatkan prestasi kinerja karyawan adalah dengan menghubungkan kompensasi dan perkembangan karyawan.

Kemajuan perusahaan di pengaruhi oleh faktor -faktor lingkungan yang bersifat intenal dan eksternal. Sejauh mana tujuan perusahaan telah tercapai dapat dilihat dari seberapa besar perusahaan memenuhi tuntutan lingkungannya (Veithzal, 2005).

Hal lain yang menjadi perhatian perusahaan adalah kepuasan kerja karyawannya. Jika dalam bekerja karyawan tidak merasakan kenyamanan, kurang dihargai, tidak bisa mengembangkan segala potensi yang mereka miliki. Dalam bekerja karyawan tidak hanya sekedar melakukan pekerjaan, tetapi terkait juga dengan aspek lain seperti berinteraksi dengan teman sekerja dan atasan, mengikuti aturan - aturan dan lingkungan kerja tertentu yang seringkali tidak memadai atau kurang disukai (Hariandja, 2002).

Kepuasan kerja pada dasarnya merupakan hal yang bersifat individual. Setiap individual memiliki tingkat kepuasan kerja yang berbeda - beda sesuai dengan keinginan dan sistem nilai yang dianutnya (Handoko, 2002). Semakin banyak aspek dalam pekerjaannya yang sesuai dengan keinginan dan sistem nilai yang dianut individu, semakin tinggi tingkat kepuasan yang didapat. Sebaliknya, semakin banyak aspek dalam pekerjaannya yang tidak sesuai, semakin rendah tingkat kepuasan yang didapat.

Penelitian ini bertujuan untuk menganalisis pengaruh kompensasi, motivasi kerja, dan lingkungan kerja dalam membentuk kepuasan kerja dan meningkatkan kinerja pegawai. Secara teoritis, penelitian ini diharapkan dapat mengembangkan ilmu pengetahuan, khususnya Manajemen Sumberdaya Manusia terutama bagi akademisi yang ingin menganalisis pengaruh kompensasi, motivasi kerja, lingkungan kerja dan kepuasan kerja terhadap kinerja karyawan. Secara praktis, merupakan bahan masukan dan evaluasi praktek lapangan perbankan, tentang manajemen sumberdaya manusia karyawannya. 
Dari uraian di atas, masalah yang akan dibahas dalam penelitian ini adalah sebagai berikut :

1. Apakah kompensasi berpengaruh terhadap kepuasan kerja karyawan.

2. Apakah kerja berpengaruh terhadap kepuasan kerja karyawan.

3. Apakah lingkungan kerja berpengaruh terhadap kepuasan kerja karyawan.

4. Apakah kompensasi berpengaruh terhadap kinerja karyawan.

5. Apakah motivasi kerja berpengaruh terhadap kinerja karyawan.

6. Apakah lingkungan kerja berpengaruh terhadap kinerja karyawan.

7. Apakah kepuasan kerja berpengaruh terhadap kinerja karyawan.

\section{TINJAUAN TEORITIS}

Kinerja Karyawan

Handoko (2002) mengistilahkan kinerja (performance) dengan prestasi kerja yaitu proses melalui mana organisasi mengevaluasi atau menilai prestasi kerja karyawan. Hariandja (2002) mengatakan kinerja merupakan hasil kerja yang dihasilkan oleh pegawai atau perilaku nyata yang ditampilkan sesuai peranannya dalam organisasi. Kinerja juga berarti hasil yang dicapai seseorang baik kualitas maupun kuantitas sesuai dengan tanggungjawab yang diberikan kepadanya. Kinerja karyawan adalah tingkat hasil kerja karyawan dalam pencapaian persyaratan pekerjaan yang diberikan (Simamora, 2004).

Deskripsi dari kinerja menyangkut tiga komponen penting yaitu : 1) Tujuan, yang akan memberikan arah dan memengaruhi bagaimana seharusnya perilaku kerja yang diharapkan organisasi terhadap setiap personel. 2) Ukuran, yang dibutuhkan untuk mengetahui apakah seorang personel telah mencapai kinerja yang diharapkan. Karena itu standar kinerja untuk setiap tugas dan jabatan personal memegang peranan penting. 3) Penilaian, yang secara reguler dikaitkan dengan proses pencapaian tujuan kinerja setiap personel.

Manfaat kinerja pegawai antara lain adalah untuk menganalisa dan mendorong efisiensi produksi, menentukan target atau sasaran yang nyata, lalu untuk pertukaran informasi antaratenaga kerja dan manajemen yang berhubungan terhadap masalah-masalah yang berkaitan (Swietenia, 2009). Adapun indikator kinerja karyawan menurut Guritno dan Waridin (2005) adalah mampu meningkatkan target pekerjaan, mampu menyelesaikan pekerjaan tepat waktu, mampu menciptakan inovasi dan kreativitas dalam menyelesaikan pekerjaan, serta mampu maminimalkan kesalahan pekerjaan.

Penilaian kinerja (performance appraisal) memainkan peranan penting dalam peningkatan motivasi kerja. Karyawan menginginkan dan memerlukan balikan berkenan dengan prestasi mereka, dan penilaian menyediakan kesempatan untuk memberikan balikan kepada mereka. Jika kinerja tidak sesuai dengan standar, penilaian memberikan kesempatan untuk meninjau kemajuan karyawan dan menyusun rencana peningkatan kinerja. Penilaian kinerja merupakan upaya membandingkan prestasi aktual karyawan dengan yang diharapkan darinya (Dessler 2000).

Dalam penilaian kinerja karyawan tidak hanya menilai hasil fisik, tetapi pelaksanaan pekerjaan secara keseluruhan yang menyangkut berbagai bidang seperti kemampuan kerja, kerajinan, kedisiplinan, hubungan kerja atau hal-hal 
khusus sesuai dengan bidang dan level pekerjaan yang dijabatnya. Ada lima faktor dalam penilaian kinerja, yaitu prestasi pekerjaan, meliputi akurasi, ketelitian, keterampilan, dan penerimaan keluaran; Kuantitas pekerjaan, meliputi volume keluaran dan kontribusi; kepemimpinan yang diperlukan, meliputi membutuhkan saran, arahan atau perbaikan; kedisiplinan, meliputi kehadiran, sanksi, warkat, regulasi, dapat dipercaya/diandalkan dan ketepatan waktu; komunikasi, meliputi hubungan antar karyawan maupun dengan pimpinan melalui media komunikasi (Dessler, 2000).

\section{Kompensasi}

Pada dasarnya manusia bekerja juga ingin memeroleh uang untuk memenuhi kebutuhan hidupnya. Untuk itu karyawan menghargai kerja keras dan semakin menunjukkan loyalitasnya terhadap perusahaan. Perusahaan memberikan penghargaan terhadap prestasi kerja karyawan yaitu dengan jalan memberikan kompensasi. Salah satu cara manajemen untuk meningkatkan prestasi kerja, memotivasi dan meningkatkan kinerja para karyawan adalah melalui kompensasi (Mathis dan Jackson, 2000).

Kompensasi penting bagi karyawan sebagai individu karena besarnya kompensasi mencerminkan ukuran karya mereka di antara para karyawan itu sendiri, keluarga dan masyarakat (Handoko, 1993). Kompensasi acapkali juga disebut penghargaan dan dapat didefinisikan sebagai setiap bentuk penghargaan yang diberikan kepada karyawan sebagai balas jasa atas kontribusi yang mereka berikan kepada organisasi (Panggabean, 2002).

Menurut Dessler dalam Indriyani (2009), kompensasi mempunyai tiga komponen, yaitu pembayaran uang secara langsung (direct financial payment) dalam bentuk gaji, dan intensif atau bonus/komisi, pembayaran tidak langsung (indirect payment) dalam bentuk tunjangan dan asuransi, serta ganjaran non finansial (non financial rewards) seperti jam kerjayang luwes dan kantor yang bergengsi.

Tujuan pemberian kompensasi (balas jasa) antara lain adalah ikatan kerja sama, kepuasan kerja, pengadaan efektif, motivasi, stabilitas karyawan, disiplin, pengaruh Serikat Buruh dan pemerintah. Sedangkan sistem pembayaran kompensasi yang umum diterapkan adalah sistem waktu, sistem hasil (output), dan sistem borongan (Hasibuan, 2002),

\section{Motivasi Kerja}

Perilaku manusia sebenarnya hanyalah cerminan yang paling sederhana motivasi dasar mereka. Perilaku manusia ditimbulkan atau dimulai dengan adanya motivasi. Agar perilaku manusia sesuai dengan tujuan organisasi,, harus ada perpaduan antara motivasi akan pemenuhan kebutuhan mereka sendiri dan permintaan organisasi. Menurut Robbins (2007) motivasi merupakan proses yang berperan pada intensitas, arah, dan lamanya berlangsung upaya individu ke arah pencapaian sasaran. Motivasi yaitu faktor-faktor yang mengarahkan dan mendorong perilaku atau keinginan seseorang untuk melakukan suatu kegiatan yang dinyatakan dalam bentuk usaha keras atau lemah (Hariandja, 2002). Motivasi merupakan keadaan di mana usaha dan kemauan keras seseorang diarahkan kepada pencapaian hasil- 
hasil atau tujuan tertentu (Sopiah, 2008). Hasil-hasil yang dimaksud bisa berupa produktivitas, kehadiran atau perilaku kerja kreatif lainnya. Dari beberapa pengertian motivasi di atas, dapat disimpulkan motivasi timbul dari diri sendiri untuk mencapai suatu tujuan tertentu, dan juga bisa oleh dorongan orang lain. Tetapi motivasi yang paling baik adalah dari diri sendiri karena dilakukan tanpa paksaan, juga setiap individu memiliki motivasi yang berbeda untuk mencapai tujuannya.

Salah satu aspek memanfaatkan pegawai ialah pemberian motivasi (daya perangsang) kepada pegawai, pemberian kegairahan bekerja kepada pegawai untuk memberi manfaat kepada perusahaan, demi tercapainya tujuan perusahaan. Ini berarti setiap pegawai memberi kemungkinan manfaat bagi perusahaan, diusahakan oleh pemimpin agar kemungkinan itu menjadi kenyataan. Usaha untuk merealisasi kemungkinan tersebut ialah dengan memberikan motivasi, yang menentukan perilaku pegawai untuk bekerja. Dengan demikian dapat dikatakan motivasi pada dasarnya adalah kondisi mental yang mendorong dilakukannya suatu tindakan (action atau activities) dan memberikan kekuatan yang mengarah kepada pencapaian kebutuhan, memberi kepuasan ataupun mengurangi ketidak seimbangan.

\section{Lingkungan Kerja}

Setiap perusahaan selalu berusaha untuk menciptakan lingkungan kerja yang menyenangkan, karena akan berpengaruh terhadap peningkatan kinerja perusahaan. Dalam menjalankan kegiatannya selalu memerhatiakan faktor faktor yang ada di dalam maupun di luar perusahaan. Lingkungan kerja adalah segala sesuatu yang ada di sekitar para pekerja yang memengaruhi tugas-tugas yang dibebankan. Secara umum lingkungan kerja merupakan lingkungan di mana para karyawan melaksanakan tugas dan pekerjaannya. Suatu sistem produksi yang baik tidak akan di laksanakan dengan efektif apabila tidak didukung oleh lingkungan kerja yang memuaskan. Segala mesin, peralatan yang dipasang dan dipergunakan dalam pabrik tidak akan banyak berarti, apabila para karywan tdak dapat bekerja dengan baik, yang disebabkan karena faktor lingkungan kerja tidak memenuhi persyaratan yang ditentukan.

Secara garis besar lingkungan kerja terbagi menjadi dua jenis (Sedarmayanti, 2001) yaitu lingkungan kerja fisik, mencakup semua keadaan yang berbentuk fisik yang terdapat disekitar tempat kerja yang dapat memengaruhi karyawan baik secara langsung maupun tidak langsung. Lingkungan kerja non fisik, adalah semua keadaan yang terjadi yang berkaitan dengan hubungan kerja baik hubungan dengan atasan maupun hubungan sesama rekan kerja, ataupun hubungan dengan bawahan. Pelayanan para tenaga kerja merupakan salah satu faktor yang penting untuk membentuk lingkungan kerja di dalam perusahaan. Dengan pelayanan yang baik oleh perusahaan, para tenaga kerja akan memeroleh kepuasan kerja.

Bentuk pelayanan para tenaga meliputi pelayanan makanan, pelayanan kesehatan bagi tenaga kerja dan keluarga, penyediaan kamar mandi dan kamar kecil, serta kondisi kerja. Kondisi kerja merupakan kondisi dalam perusahaan di mana tenaga kerja berada, yang dapat dipersiapkan oleh manajemen 
perusahaan. Kondisi kerja yang kurang memadai akan menimbulkan penurunan produktivitas. Beberapa kondisi kerja yang dapat dipersiapkan oleh manajemen perusahaan antara lain penerangan, temperatur udara atau suhu udara, kebersihan, ruang gerak, pewarnaan, kebisingaan, dan keamanan kerja. Indikator lingkungan kerja yang baik antara lain tata ruang yang tepat dan mampu memberikan keleluasaan bekerja para karyawan, pencahayaan memedai, sehingga mampu mendukung kinerja karyawan, drainase dan ventilasi yang baik sehingga tercipta suhu dan kelembapan ruangan, pengaturan ruang yang memungkinkan penciptaan ruangan yang tenang dari suara bising.

\section{Kepuasan Kerja}

Kepuasan kerja merupakan bentuk perasaan seseorang terhadap pekerjaannya, situasi kerja dan hubungan dengan rekan kerja. Dengan demikian kepuasan kerja penting untuk dimiliki oleh karyawan, di mana mereka dapat berinteraksi dengan lingkungan kerjanya sehingga pekerjaan dapat dilaksanakan dengan baik untuk mencapai tujuan perusahaan. Menurut Handoko (2000) "Kepuasan kerja (job satisfaction) adalah keadaan emosional yang menyenangkan atau tidak menyenangkan bagaimana para karyawan memandang pekerjaan mereka. Kepuasan kerja mencerminkan perasaan seseorang terhadap pekerjaannya.

Banyak faktor yang dapat menjadi penentu bagi kepuasan pegawai, salah satunya adalah pekerjaan itu sendiri. Hackman dan Oldham (Robbins (2007), inti dari pekerjaan adalah sebagai skill varienty, di mana semakin banyak variasi tugas yang dilakukan oleh pegawai dalam pekerjaannya, semakin menantang pekerjaan bagi mereka. Task identity, yaitu sejauh mana pekerjaan menuntut diselesaikan secara utuh dan dapat dikenali. Task significance, yaitu sejauh apa dampak pekerjaan yang dilakukan dapat memengaruhi pekerjaan atau bahkan kehidupan orang lain. Hal ini akan membawa dampak penghargaan psikologis. Autonomy, yaitu sejauh mana pekerjaan memberi kebebasan, ketidakketergantungan, dan keleluasaan untuk mengatur jadwalnya, membuat keputusan dan menentukan prosedur pekerjaan yang dipakai. Serta feedback, yaitu sejauh mana pelaksanaan kegiatan pekerjaan menghasilakan informasi bagi individu mengenai keefektifan kinerjanya.

Kepuasan kerja pegawai dipengaruhi oleh tanggapan terhadap nilai intrinsic dan extrinsic reward. Yang dimaksud dengan nilai intrinsic reward yaitu timbulnya suatu perasaan dalam diri pegawai karena pekerjaan yang dilakukan. Yang termasuk dalam extrinsic reward adalah perasaan suka akan pekerjaannya, rasa tanggung jawab, tantangan dan pengakuan. Extrinsic reward adalah situasi yang terjadi di luar pekerjaan, misalnya karena bekerja dengan baik sesuai dengan apa yang diharapkan oleh perusahaan maka pegawai mendapatkan upah, gaji, dan bonus.

Hubungan Kompensasi, Motivasi Kerja, Lingkungan Kerja, Kepuasan kerja dan Kinerja Karyawan

Upah merupakan suatu penerimaan sebagai suatu imbalan dan pemberi jasa kepada penerima jasa, dan sebagai faktor yang pentig dalam upaya meningkatkan kinerja karyawan dan sebagai perangsang dalam mendorong 
karyawan tercapainya tujuan perusahaan. Dengan pemberian upah, diharapkan seorang tenaga kerja dapat untuk produktif dan mempun yai tanggung jawab penuh terhadap tugasnya, sehingga target volume produksi perusahaan dapat terpenuhi. Selain itu dengan adanya tenaga kerja dan pihak perusahaan akan dapat terjalin dengan baik, sehingga seluruh tenaga kerjanya akan berusaha meningkatkan kinerjanya. Hasil penelitian sebelumnya menemukan adanya pengaruh kompensasi terhadap kepuasan dan kinerja karyawan (Muljani, 2012; Aritonang, 2005; Hakim, 2011; Dhermawan, dkk., 2012; Sujana, 2012; Yahyo, dkk., 2013; Kasenda, 2013; Damayanti, dkk., 2013; dan Sahlan, dkk., 2015). Mengingat tenaga kerja merupakan faktor yang terpenting dalam pelaksanaan proses produksi, diperlukan tenga kerja yang mempunyai ketrampilan dan keahlian demi kelangsungan hidup perusahaan. Lingkungan kerja merupakan alat perkakas yang akan berpengaruh terhadap kinerja karyawan jika lingkungan yang ada di perusahaan itu baik. Lingkungan kerja yang menyenangkan bagi karyawan melalui pengikatan hubungan yang harmonis dengan atasan maupun bawahan, serta didukung oleh sarana dan prasarana yang memadai yang ada di tempat bekerja akan membawa dampak positif bagi karyawan, sehingga kinerja meningkat. Dengan adanya lingkungan kerja yang baik, akan tercipta suasana kerja yang menyenangkan.

Hasil penelitian terdahulu menunjukan pengaruh lingkungan kerja terhadap kepuasan dan kinerja karyawan (Dhermawan, dkk., 2012; Yahyo, dkk., 2013; Gardjito, dkk., 2014; dan Sahlan, dkk., 2015). Motivasi kerja juga berpengaruh positif dan signifikan terhadap kinerja karyawan (Noski, 2000; Prasetyo dan Wahyuddin, 2003; Koesmono, 2005; Listianto dan Setiaji, 2007; Brahmasari dan Suprayetno, 2008; Subyantoro, 2009; Purnomo dan Cholil, 2010; Suwardi dan Utomo, 2011; Hakim, 2011; Susanty dan Baskoro, 2012; Sari, dkk., 2012; Sudjana, 2012; Dhermawan, dkk., 2012; Muslih, 2012; Damayanti, dkk., 2013; Yahyo, dkk., 2013; Kasenda, 2013; Sajangbati, 2013; Sari, 2014; Gardjito, dkk., 2014; Juniantara dan Riana, 2015). Hubungan kepuasan Kerja dengan kinerja lebih tepat disebut sebagai "mitos manajemen" dan sulit untuk menetapkan ke arah mana hubungan sebab akibat di antara keduanya. Namun dari berbagai penelitian ditemukan bukti bahwa organisasi dengan karyawan yang lebih puas cenderung lebih efektif dibandingkan organisasi yang memiliki karyawan yang kurang puas. (Robbins,2007). Beberapa hasil penelitian menunjukan adanya pengauh kepuasan kerja terhadap kinerja karyawan (Aritonang, 2005; Koesmono, 2005; Widodo, 2006; Brahmasari dan Suprayetno, 2008; Tobing, 2009; Suwardi dan Utomo, 2011; Muslih, 2012; Dhermawan, dkk., 2012; Sajangbati, 2013; Juniantara dan Riana, 2015; dan Sahlan, dkk., 2015)

Dari uraian di atas, maka dapat dikembangkan suatu kerangka konseptual pada Gambar 1 berikut. 


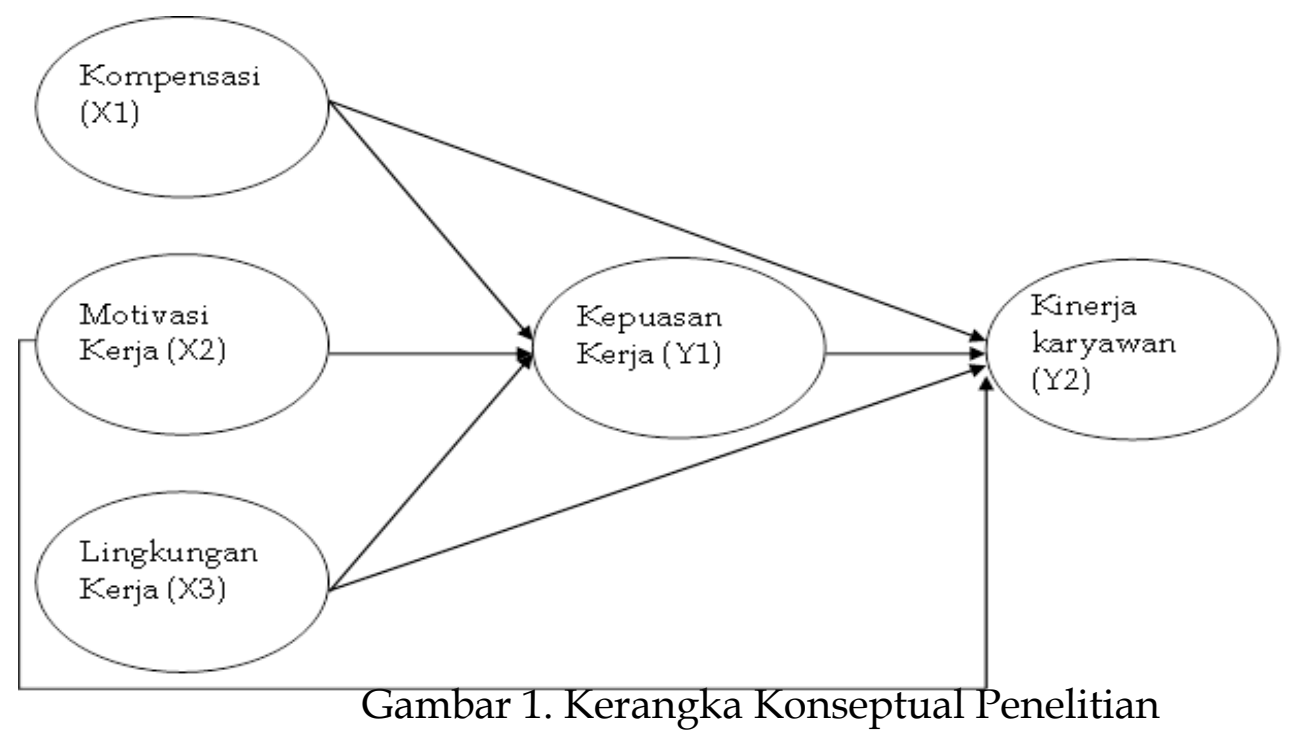

Dari uraian di atas, rumusan hipotesis yang akan diuji dalam penelitian ini sebagai berikut :

1. Kompensasi berpengaruh positif dan signifikan terhadap kepuasan kerja pegawai.

2. Motivasi kerja berpengaruh positif dan signifikan terhadap kepuasan kerja pegawai.

3. Lingkungan kerja berpengaruh positif dan signifikan terhadap kepuasan kerja pegawai.

4. Kompensasi berpengaruh positif dan signifikan terhadap kinerja pegawai.

5. Motivasi kerja berpengaruh positif dan signifikan terhadap kinerja pegawai.

6. Lingkungan kerja berpengaruh positif dan signifikan terhadap kinerja pegawai.

7. Kepuasan kerja berpengaruh positif dan signifikan terhadap kinerja pegawai.

\section{METODE PENELITIAN}

Penelitian ini adalah penelitian explanatory yang menjelaskan hubungan kausal dan pengujian hipotesa. Penelitian ini dilakukan di Kota Ambon selama bulan bulan Juli - Agustus 2017. Data primer diperoleh berdasarkan daftar pertanyaan yang diberikan secara tertulis kepada para pegawai PT Bank Maluku Maluku Utara Cabang Ambon. Sementara data sekunder diperoleh melalui literatur, jurnal ilmiah, majalah maupun data dokumen yang sekiranya diperlukan untuk penelitian ini. Populasi penelitian ini adalah 103 orang pegawai PT Bank Maluku Maluku Utara Cabang Ambon. Mengingat jumlah populasi terjangkau, dalam penelitian ini tidak dilakukan pengambilan sampel. Teknik analisis yang digunakan untuk menguji kebenaran hipotesis yang diajukan adalah analisis deskriptif dan analisis jalur (path analysis). 


\section{PEMBAHASAN}

Karakteristik Responden

Responden penelitian ini berjumlah 103 orang pegawai PT Bank Maluku Maluku Utara Cabang Ambon. Hasil tabulasi menunjukan mereka terdiri dari 53 orang $(51,5 \%)$ laki-laki dan 50 orang $(48,5 \%)$ perempuan yang telah menjadi pegawai PT Bank Makuku dan Maluku Utara Cabang Ambon kurang dari 5 tahun sebanyak 25 orang (24,3\%), antara 5-10 tahun sebanyak 51 orang (49,5\%), dan yang lebih dari 10 tahun sebanyak 27 orang (26,2\%). Responden yang berada pada kelompok usia kurang dari 30 tahun sebnayak 18 orang (17,5\%), antara 31-50 tahun sebanyak 49 orang, dan selebihnya berada pada kelompok usia lebih dari 50 tahun sebanyak 36 orang $(35,0 \%)$. Selanjutnya responden penelitian ini sebagian besar memiliki tingkat pendidikan sarjana sebanyak 37 orang $(35,9 \%)$, diploma sebanyak 32 orang $(31,1 \%)$, Pascasarjana sebanyak 5 orang $(4,9 \%)$, dan SMA/sederajat sebanyak 29 orang $(28,2 \%)$. Dari status perkawinan, responden penelitian ini yang sudah menikah sebanyak 85 orang $(82,5 \%)$, yang belum menikah sebanyak 14 orang $(13,6 \%)$, janda/duda sebanyak 4 orang $(3,9 \%)$. Sementara itu, responden penelitian ini yang memiliki penghasilan per bulan antara Rp 5.000.000,- sampai dengan Rp 10.000.000,adalah sebanyak 44 orang $(42,7 \%)$, lebih dari Rp. 10.000.000,- sebanyak 58 orang $(56,3 \%)$, dan selebihnya adalah mereka yang memiliki penghasilan kurang dari Rp 5.000.000,- sebanyak 1 orang (1,0\%). Selanjutnya responden yang memiliki jumlah tanggungan keluarga kurang dari 3 orang sebanyak 36 orang $(35,0 \%)$, jumlah tanggungan antara 3-5 orang sebanyak 33 orang $(32,0 \%)$, serta jumlah tanggungan keluarga lebih dari 5 orang sebanyak 34 orang $(33,0 \%)$.

\section{Hasil Penelitian}

Analisis jalur digunakan untuk mengukur besarnya kontribusi atau pengaruh variabel bebas terhadap variabel terikat, baik pengaruh langsung maupun pengaruh tidak langsung melalui hubungan dengan variabel bebas kompensasi, motivasi kerja, lingkungan kerja, dengan kepuasan kerja dan kinerja. Hasil pengujian persamaan I disajikan dalam tabel berikut.

Tabel 1. Hasil Pengujian Persamaan Regresi I

\begin{tabular}{|c|c|c|c|c|c|c|c|}
\hline \multirow{2}{*}{\multicolumn{3}{|c|}{ Model }} & \multicolumn{2}{|c|}{$\begin{array}{l}\text { Unstandardized } \\
\text { Coefficients }\end{array}$} & \multirow{2}{*}{$\begin{array}{c}\text { Standardized } \\
\text { Coefficients } \\
\text { Beta }\end{array}$} & \multirow[b]{2}{*}{$\mathrm{t}$} & \multirow[b]{2}{*}{ Sig. } \\
\hline & & & B & Std. Error & & & \\
\hline \multirow[t]{8}{*}{1} & (Const & & ,077 & ,046 & & 1,655 & ,001 \\
\hline & Kompe & sasi & 142 & ,027 & 134 & 5,344 & ,001 \\
\hline & Motiva & i Kerja & 279 & ,024 & ,286 & 11,432 & ,000 \\
\hline & Lingku & gan Kerja & 260 & ,024 & ,221 & 10,671 & ,003 \\
\hline & $\mathrm{R}$ & $=0,997$ & & & & & \\
\hline & $\mathrm{R}^{2}$ & $=0,995$ & & & & & \\
\hline & F & $=6080,557$ & & & & & \\
\hline & Sig & $=0,000$ & & & & & \\
\hline
\end{tabular}


Sumber : Hasil Pengolahan, 2017

Berdasarkan tabel 1 di atas, model persamaan I yang diperoleh dari hasil penelitian ini dapat dituliskan dalam bentuk persamaan regresi berganda yaitu

$\mathrm{Y}=0,077+0,134 \mathrm{X}_{1}+0,286 \mathrm{X}_{2}+0,221 \mathrm{X}_{3}+0,005$

Dari hasil persamaan regresi tersebut di atas maka dapat dijelaskan :

$\mathrm{b}_{0}=0,077$ merupakan nilai konstanta, artinya tanpa adanya kompensasi, motivasi kerja dan lingkungan kerja, kepuasan kerja pegawai PT Bank Maluku Maluku Utara Cabang Ambon sebesar 0,077 atau 7,7\%.

$\mathrm{b}_{1}=0,134$ menunjukan apabila kompensasi meningkat, sedangkan faktorfaktor lainnya tetap akan memengaruhi kepuasan kerja sebesar 0,134 atau $13,4 \%$.

$\mathrm{b}_{2}=0,286$ menunjukan apabila motivasi kerja meningkat, sedangkan faktorfaktor lainnya tetap akan memengaruhi kepuasan kerja sebesar 0,286 atau $28,6 \%$.

$\mathrm{b}_{3}=0,221$ menunjukan apabila lingkungan kerja meningkat, sedangkan faktor-faktor lainnya tetap akan memengaruhi kepuasan kerja sebesar 0,221 atau $22,1 \%$.

$\varepsilon=0,005$ menunjukan nilai residu atau nilai pengaruh dari variabel lain yang tidak diikutkan dalam penelitian ini.

Nilai $\mathrm{R}=0,997$ atau 99,7\% menunjukan hubungan kompensasi, motivasi kerja dan lingkungan kerja dengan kepuasan kerja, sedangkan nilai koefisien determinasi $\mathrm{R}^{2}=0,995$ menunjukan kompensasi, motivasi kerja, dan lingkungan kerja secara bersama-sama memengaruhi kepuasan kerja sebesar $99,5 \%$, sedangkan sisanya 0,5\% dipengaruhi oleh faktor lain yang tidak ikut diteliti. Hasil ini menunjukan kompensasi, motivasi kerja dan lingkungan kerja memberikan kontribusi sebesar 99,5\% terhadap pembentukan kepuasan kerja pegawai PT Bank Maluku Maluku Utara Cabang Ambon.

Selanjutnya ringkasan hasil pengujian persamaan II dalam bentuk persamaan regresi berganda disajikan dalam tabel berikut.

Tabel 2. Hasil Analisis Regresi Persamaan II

\begin{tabular}{|c|c|c|c|c|c|c|c|}
\hline \multirow{2}{*}{\multicolumn{2}{|c|}{ Model }} & & \multicolumn{2}{|c|}{$\begin{array}{l}\text { Unstandardized } \\
\text { Coefficients }\end{array}$} & \multirow{2}{*}{$\begin{array}{c}\text { Standardized } \\
\text { Coefficients } \\
\text { Beta } \\
\end{array}$} & \multirow[b]{2}{*}{$\mathrm{t}$} & \multirow[b]{2}{*}{ Sig. } \\
\hline & & & B & Std. Error & & & \\
\hline \multirow[t]{9}{*}{1} & (Const & & 711 & 214 & & 3,321 & ,004 \\
\hline & Kompe & sasi & ,934 & 125 & 921 & 7,495 & ,000 \\
\hline & Motiva & Kerja & 662 & 169 & 861 & 3,906 & ,002 \\
\hline & Lingku & gan Kerja & 252 & ,074 & 276 & 3,429 & 003 \\
\hline & Kepua & n Kerja & ,435 & 147 & ,562 & 2,971 & ,000 \\
\hline & $\mathrm{R}$ & $=0,899$ & & & & & \\
\hline & $\mathrm{R}^{2}$ & $=0,809$ & & & & & \\
\hline & $F_{\text {hitung }}$ & $=103,566$ & & & & & \\
\hline & Sig & $=0,000$ & & & & & \\
\hline
\end{tabular}

Sumber : Hasil Pengolahan, 2017 
Berdasarkan tabel 2 di atas, model persamaan II yang diperoleh dari hasil penelitian ini dapat dituliskan dalam bentuk persamaan regresi berganda yaitu

$\mathrm{Y}=0,711+0,921 \mathrm{X}_{1}+0,861 \mathrm{X}_{2}+0,276 \mathrm{X}_{3}+0,562 \mathrm{Y}_{1}+0,191$

Dari hasil persamaan regresi tersebut di atas maka dapat dijelaskan :

$\mathrm{b}_{0}=0,711$ merupakan nilai konstanta, artinya tanpa adanya kompensasi, motivasi kerja, lingkungan kerja dan kepuasan kerja maka kinerja pegawai PT Bank Maluku Maluku Utara Cabang Ambon sebesar 0,711 atau 71,1\%.

$\mathrm{b}_{1}=0,921$ menunjukan apabila kompensasi meningkat sedangkan faktorfaktor lainnya tetap akan memengaruhi kinerja sebesar 0,921 atau 92,1\%.

$\mathrm{b}_{2}=0,861$ menunjukan apabila motivasi kerja meningkat sedangkan faktorfaktor lainnya tetap akan memengaruhi kinerja sebesar 0,861 atau 86,1\%.

$\mathrm{b}_{3}=0,276$ menunjukan apabila lingkungan kerja meningkat sedangkan faktorfaktor lainnya tetap akan memengaruhi kinerja sebesar 0,276 atau 27,6\%.

$\mathrm{b}_{4}=0,562$ menunjukan apabila kepuasan kerja meningkat sedangkan faktorfaktor lainnya tetap akan memengaruhi kinerja sebesar 0,562 atau 56,2\%.

$\varepsilon=0,191$ menunjukan nilai residu atau nilai pengaruh dari variabel lain yang tidak diikutkan dalam penelitian ini.

Nilai $\mathrm{R}=$ 0,997 atau 99,7\% menunjukan hubungan kompensasi, motivasi kerja, lingkungan kerja dan kepuasan kerja dengan kinerja pegawai, sedangkan nilai koefisien determinasi $\mathrm{R}^{2}=0,995$ menunjukan kompensasi, motivasi kerja, lingkungan kerja, dan kepuasan kerja secara bersama-sama memengaruhi kinerja sebesar 99,5\%, sedangkan sisanya 19,1\% dipengaruhi oleh faktor lain yang tidak ikut diteliti. Hasil ini menunjukan kompensasi, motivasi kerja, lingkungan kerja dan kepuasan kerja memberikan kontribusi sebesar 99,5\% terhadap kinerja pegawai PT Bank Maluku Maluku Utara Cabang Ambon.

\section{Pengujian Hipotesis}

Tabel 1 di atas menunjukan nilai t-hitung variabel kompensasi sebesar 5,344 dengan level signifikansi 0,001 sementara nilai t-tabel adalah 2,63 dengan demikian nilai t-hitung $>$ t-tabel, sehingga hipotesis 1 yang diajukan dalam penelitian ini dapat diterima, di mana kompensasi berpengaruh positif dan signifikan terhadap kepuasan kerja pegawai PT Bank Maluku Maluku Utara Cabang Ambon.

Kemudian nilai t-hitung variabel motivasi kerja sebesar 11,432 dengan level signifikansi 0,000 sementara nilai t-tabel adalah 2,63 dengan demikian nilai $t$ hitung $>$ t-tabel, sehingga hipotesis 2 yang diajukan dalam penelitian ini dapat diterima, di mana motivasi kerja berpengaruh positif dan signifikan terhadap kepuasan kerja pegawai PT Bank Maluku Maluku Utara Cabang Ambon.

Sementara nilai t-hitung variabel lingkungan kerja sebesar 10,671 dengan level signifikansi 0,003 sementara nilai t-tabel adalah 2,63 dengan demikian nilai thitung $>$ t-tabel, sehingga hipotesis 3 yang diajukan dalam penelitian ini dapat diterima, di mana lingkungan kerja berpengaruh positif dan signifikan terhadap kepuasan kerja pegawai PT Bank Maluku Maluku Utara Cabang Ambon. 
Tabel 2 di atas menunjukan nilai t-hitung variabel kompensasi sebesar 7,495 dengan level signifikansi 0,000 sementara nilai t-tabel adalah 2,63 dengan demikian nilai t-hitung $>\mathrm{t}$-tabel, sehingga hipotesis 4 yang diajukan dalam penelitian ini dapat diterima, di mana kompensasi berpengaruh positif dan signifikan terhadap kinerja pegawai PT Bank Maluku Maluku Utara Cabang Ambon.

Kemudian nilai t-hitung variabel motivasi kerja sebesar 3,06 dengan level signifikansi 0,002 sementara nilai t-tabel adalah 2,63 dengan demikian nilai thitung $>\mathrm{t}$-tabel, sehingga hipotesis 5 yang diajukan dalam penelitian ini dapat diterima, di mana motivasi kerja berpengaruh positif dan signifikan terhadap kinerja pegawai PT Bank Maluku Maluku Utara Cabang Ambon.

Sementara nilai t-hitung variabel lingkungan kerja sebesar 3,429 dengan level signifikansi 0,003 sementara nilai t-tabel adalah 2,63 dengan demikian nilai thitung $>\mathrm{t}$-tabel, sehingga hipotesis 6 yang diajukan dalam penelitian ini dapat diterima, di mana lingkungan kerja berpengaruh positif dan signifikan terhadap kinerja pegawai PT Bank Maluku Maluku Utara Cabang Ambon.

Sedangkan nilai t-hitung variabel kepuasan kerja sebesar 2,971 dengan level signifikansi 0,000 sementara nilai $t$-tabel adalah 2,63 dengan demikian nilai $t$ hitung $>\mathrm{t}$-tabel, sehingga hipotesis 7 yang diajukan dalam penelitian ini dapat diterima, di mana kepuasan kerja berpengaruh positif dan signifikan terhadap kinerja pegawai PT Bank Maluku Maluku Utara Cabang Ambon.

\section{Pengaruh Variabel Bebas terhadap Variabel Terikat}

Dari hasil perhitungan dalam tabel 1 dan 2 di atas, diketahui pengaruh variabel masing-masing variabel bebas terhadap variabel mediasi dan variabel terikat. Untuk mengetahui bersanya pengaruh tidak langsung masing-masing variabel bebas terhadap variabel terikat, dilakukan perhitungan dengan cara mengalikan nilai pengaruh langsung masing-masing variabel bebas terhadap variabel mediasi dengan nilai pengaruh langsung variabel mediasi terhadap variabel terikat. Hasil perhitungan pengaruh tidak langsung kompensasi terhadap kinerja melalui kepuasan kerja adalah 0,134 × 0,562 =0,075221. Besarnya pengaruh tidak langsung motivasi kerja terhadap inerja melalui kepuasan kerja adalah $0,286 \times 0,562=0,16111$. Sedangkan besarnya pengaruh tidak langsung lingkungan kerja terhadap kinerja melalui kepuasan kerja adalah $0,221 \times 0,562=0,124071$. Dari hasil perhitungan tersebut, ternyata besarnya pengaruh langsung masing-masing variabel bebas terhadap variabel terikat lebih besar daripada pengaruh tidak langsung.

\section{Pembahasan}

Hasil penelitian ini menunjukan kompensasi berpengaruh positif baik secara langsung maupun tidak langsung terhadap kepuasan kerja dan kinerja pegawai PT Bank Maluku dan Maluku Utara Cabang Ambon, dengan pengaruh langsung lebih besar daripada pengaruh tidak langsung. Hal ini berarti untuk meningkatkan kinerja pegawai, pihak manajemen PT Bank Maluku Maluku Utara Cabang Ambon hendaknya memberi perhatian pada pemberian kompensasi, baik kompensasi finansial maupun non finansial. Pegawia yang merasakan adanya keadilan dalam pemberian kompensasi dari perusahaannya 
cenderung merasakan kepuasan dalam bekerja, serta memiliki kinerja yang baik pula. Kemudian hasil perhitungan menunjukan motivasi kerja berpengauh positif dan signifikan terhadap kepuasan kerja dan kinerja pegawai PT Bank Maluku Maluku Utara Cabang Ambon. Hal ini berarti untuk meningkatkan kinerja pegawainya, pihak manajemen PT Bank Maluku Maluku Utara hendaknya senantiasa memberi perhatian juga terhadap pemberian motivasi bagi para pegawainya, baik motivasi intrinsik maupun ekstrinsik. Karena pegawai yang memiliki motivasi kerja yang baik akan cenderung merasakan kepuasan dalam bekerja, dan pada gilirannya memiliki kinerja yang baik juga. Hasil perhitungan juga menunjukan lingkungan kerja memiliki pengaruh yang positif dan signifikan terhadap kepuasan kerja dan kinerja pegawai PT Bank Maluku Maluku Utara, dengan pengatuh langsung lebih besar daripada pengaruh tidak langsung. Hal ini berarti untuk meningkatkan kinerja pegawai, pihak manajemen PT Bank Maluku Maluku Utara juga hendaknya senantiasa memberi perhatian terhadap upaya penciptaan lingkungan kerja yang baik dan kondusif, terutama lingkungan internalnya. Lingkungan kerja yang baik dan kondusif, akan mendukung terciptanya suasana kerja yang menyenangkan Dengan adanya lingkungan kerja yang baik dan kondusif, ada kecenderungan bagi para pegawai untuk merasakan kepuasan dalam bekerja, sehingga mereka juga akan memiliki kinerja yang baik.

Hasil penelitian ini dapat memberikan masukan bagi pihak manajemen PT Bank Maluku Maluku Utara Cabang Ambon dalam upaya untuk mendapatkan pegawai yang berkinerja tinggi, di mana mereka dapat diwujudkan dengan memberikan perhatian pada pemberian kompensasi dan motivasi bagi para pegawainya, serta dengan menciptakan lingkungan kerja yang baik dan kondusif.

Hasil penelitian ini sejalan dengan beberapa penelitian yang telah dilakukan sebelumnya, di mana kompensasi merupakan salah satu penentu utama kepuasan kerja dan kinerja, di antaranya hasil penelitian Muljani (2012), Aritonang (2005), Hakim (2011), Dhermawan, dkk. (2012), Sujana (2012), Yahyo, dkk. (2013), Kasenda (2013), Damayanti, dkk. (2013), dan Sahlan, dkk. (2015). Hasil penelitian ini sejalan pula dengan hasil penelitian Noski (2000), Prasetyo dan Wahyuddin (2003), Koesmono (2005), Listianto dan Setiaji (2007), Brahmasari dan Suprayetno (2008), Subyantoro (2009), Purnomo dan Cholil (2010), Suwardi dan Utomo (2011), Hakim (2011), Susanty dan Baskoro (2012), Sari, dkk. (2012), Sudjana (2012), Dhermawan, dkk. (2012), Muslih (2012), Damayanti, dkk. (2013), Yahyo, dkk. (2013), Kasenda (2013), Sajangbati (2013), Sari (2014), Gardjito, dkk. (2014), serta Juniantara dan Riana (2015). Demikian pula hasil penelitian ini sejalan dengan hasil penelitian terdahulu yang menunjukan adanya pengaruh lingkungan kerja terhadap kepuasna kerja dan kinerja pegawai, antara lain yang dilakukan oleh Dhermawan, dkk. (2012), Yahyo, dkk. (2013), Gardjito, dkk. (2014), dan Sahlan, dkk. (2015). 


\section{PENUTUP}

\section{Kesimpulan}

Penelitian ini bertujuan menganalisis pengaruh kompensasi, motivasi kerja dan lingkungan kerja dalam membentuk kepuasan kerja dan kinerja pegawai PT Bank Maluku Maluku Utara Cabang Ambon. Hasil penelitian ini menunjukan kompensasi memiliki pengaruh yang positif dan signifikan baik langsung maupun tidak langsung terhadap kepuasan kerja dan kinerja pegawai. Selain itu, motivasi kerja juga memiliki pengaruh yang positif dan signifikan baik langsung maupun tidak langsung terhadap kepuasan kerja dan kinerja pegawai. Demikian pula lingkungan kerja memiliki pengaruh yang positif dan signifikan terhadap kepuasan kerja dan kinerja pegawai. Serta kepuasan kerja memiliki pengaruh yang positif dan signifikan terhadap kinerja pegawai.

Saran

Dalam upaya untuk membentuk kepuasan kerja dan kinerja pegawai, disarankan agar pihak manajemen PT Bank Maluku Maluku Utara hendaknya senantiasa memberi perhatian pada pemberian kompensasi finansial maupun non finansial, pemberian motivasi kerja, baik yang berisfat intrinsik maupun ekstrinsik, serta penciptaan lingkunga kerja internal yang baik dan kondusif.

\section{DAFTAR PUSTAKA}

Aritonang, Keke T. 2005. Kompensasi Kerja, Disiplin Kerja Guru dan Kinerja Guru SMP Kristen BPK Penabur Jakarta, Jurnal Pendidikan Penabur, No.04, Th.IV, Juli, 1-16

Arma, Ahmad Rijal, \& Syariati, Alim. (2015). Determinan Perilaku Kewargaan Organisasi di Pemerintah Kota PALU.Jurnal Manajemen Ide dan Inspirasi, 2(2), 24-49.

Awaluddin, Murtiadi. (2016). Pengaruh Budaya Organisasi, Kepuasan dan Lingkungan Kerja Terhadap Kinerja Dosen UIN Alauddin Makassar. In Assets (Vol. 6, No. 1, pp. 116-125).

Brahmasari, Ida Ayu dan Agus Suprayetno. 2008. Pengaruh Motivasi Kerja, Kepemimpinan dan Budaya Organisasi Terhadap Kepuasan Kerja Karyawan serta Dampaknya pada Kinerja Perusahaan (Studi kasus pada PT. Pei Hai International Wiratama Indonesia), Jurnal Manajemen dan Kewirausahaan, Vol.10, No. 2, September, 124-135

Damayanti, Agiel Puji, Susilaningsih, Sri Sumaryati. 2013. Pengaruh Kompensasi Dan Motivasi Kerja Terhadap Kinerja Karyawan Perusahaan Daerah Air Minum (PDAM) Surakarta, Jupe UNS, Vol 2, No 1, 155-168

Dessler, Gary, 2000. Manajemen Personalia (Terj. Moh. Masud). Jakarta: Erlangga

Dhermawan, Anak Agung Ngurah Bagus, I Gde Adnyana Sudibya, I Wayan Mudiartha Utama. 2012. Pengaruh Motivasi, Lingkungan Kerja, Kompetensi, dan Kompensasi Terhadap Kepuasan Kerja dan Kinerja Pegawai Di Lingkungan Kantor Dinas Pekerjaan Umum Provinsi Bali, Jurnal Manajemen, Strategi Bisnis, dan Kewirausahaan, Vol. 6, No. 2, Agustus, 173-184 
Efendi, Ahmad. (2018). Analisis Positioning Industri Perbankan Syariah di Indonesia. Al-Mashrafiyah (Jurnal Ekonomi, Keuangan dan Perbankan Syariah), 1(1).

Gardjito, Aldo Herlambang, Mochammad Al Musadieq, Gunawan Eko Nurtjahjono. 2014. Pengaruh Motivasi Kerja dan Lingkungan Kerja Terhadap Kinerja Karyawan (Studi pada Karyawan Bagian Produksi PT. Karmand Mitra Andalan Surabaya), Jurnal Administrasi Bisnis (JAB), Vol. 13, No. 1, Agustus, 1-8

Guritno, Bambang dan Waridin. 2005. Pengaruh Persepsi Karyawan Mengenai Perilaku Kepemimpinan, Kepuasan Kerja dan Motivasi Terhadap Kinerja. JRBI, Vol.1 No. 1, 63-74

Hakim, A. Khairul. 2011. Pengaruh Kompensasi dan Motivasi Terhadap Produktivitas Kerja Pegawai, Jurnal Manajemen \& Bisnis, Vol 11, No. 02 Oktober, 170-184

Handoko, Hani. 1993. Manajemen Personalia dan Sumberdaya Manusia, Edisi 2. Yogyakarta: BPFE.

Handoko, Hani. 2002. Manajemen Personalia dan Sumberdaya Manusia. Yogyakarta: BPFE

Hariandja, Marihot Tua Efendi. 2002. Manajemen Sumber Daya Manusia. Jakarta: Grasindo.

Hasibuan, Malayu S.P. 2002. Manajemen Sumber Daya Manusia Edisi Revisi. Jakarta: Bumi Aksara.

Indriyani, Lies. 2009. “Analisis Pengaruh Kompensasidan Lingkungan Kerja Terhadap Produktivitas Kerja Perawat Dengan Kepuasan Kerja Sebagai Variabel Mediasi." Jurnal Ekonomi - Manajemen - Akuntansi, No. 26, Th. XVI, 117-127

Juniantara, I Wayan dan I Gede Riana. 2015. Pengaruh Motivasi dan Kepuasan Kerja Terhadap Kinerja Karyawan Koperasi di Denpasar, E-Jurnal Ekonomi dan Bisnis Universitas Udayana, 4.09, 611-628

Kasenda, Ririvega. 2013. Kompensasi dan Motivasi Pengaruhnya Terhadap Kinerja Karyawan Pada PT. Bangun Wenang Beverages Company Manado, Jurnal EMBA Vol.1 No.3 Juni, 853-859

Koesmono, H.Teman. 2005. Pengaruh Budaya Organisasi Terhadap Motivasi dan Kepuasan Kerja serta Kinerja Karyawan Pada Sub Sektor Industri Pengolahan Kayu Skala Menengah di Jawa Timur, Jurnal Manajemen $\mathcal{E}$ Kewirausahaan, Vol. 7, No. 2, September, 171-188

Mathis, Robert L. dan John H. Jakson. 2002. Manajemen sumber daya manusia, Jakarta : Salempa Empat

Muljani, Ninuk. 2002. Kompensasi Sebagai Motivator Untuk Meningkatkan Kinerja Karyawan, Jurnal Manajemen \& Kewirausahaan Vol. 4, No. 2, September,108 - 122

Muslih, Basthoumi. 2012. Analisis Pengaruh Motivasi terhadap Kepuasan Kerja dan Kinerja Pegawai di PT Sang Hyang Seri (Persero) Regional III Malang, Jurnal Aplikasi Manajemen, Volume 10, Nomor 4, Desember, 799-810

Parmitasari, Rika Dwi Ayu., 2011. Struktur Organisasi Dan Kepuasan Kerja Karyawan. Samata: Alauddin University Press 
Purnomo, Heru dan Muhammad Cholil. 2010. Pengaruh Gaya Kepemimpinan Terhadap Kepuasan Kerja Berdasarkan Motivasi Kerja pada Karyawan Administratif di Universitas Sebelas Maret Surakarta, Jurnal Manajemen Sumberdaya Manusia, Vol. 4 No. 1 Juni, 27 - 35

Robbins, Stephen P. 2007. Perilaku Organisasi, Klaten: Indeks.

Sahlan, Nurul Ikhsan, Peggy A. Mekel, dan Irvan Trang. 2015. Pengaruh Lingkungan Kerja, Kepuasan Kerja dan Kompensasi Terhadap Kinerja Karyawan Pada PT. Bank Sulut Cabang Airmadidi, Jurnal EMBA, Vol.3 No.1 Maret, 52-62

Nurfarhana, S., \& Said, Salmah. (2017). Pendekatan Syariah dalam Pemberian Gaji dan Bonus Pengaruhnya terhadap Motivasi Kerja Pegawai. AlMashrafiyah (Jurnal Ekonomi, Keuangan dan Perbankan Syariah), 1(1).

Sajangbati, Ivonne A.S. 2013. Motivasi, Disiplin, dan Kepuasan Pengaruhnya Terhadap Kinerja Pegawai PT. Pos Indonesia (Persero) Cabang Bitung, Jurnal EMBA Vol.1 No.4 Desember 2013, 667-678

Sari, Rahmila, Mahlia Muis, Nurdjannah Hamid. 2012. Pengaruh Kepemimpinan, Motivasi, dan Stres Kerja Terhadap Kinerja Karyawan pada Bank Syariah Mandiri Kantor Cabang Makassar, Jurnal Analisis, Juni, Vol.1 No.1 : 87 - 93

Sari, Yanti Komala. 2014. Pengaruh Kepemimpinan, Motivasi dan Disiplin Kerja Terhadap Kinerja Karyawan pada PT. Patra Komala di Dumai, Jurnal Tepak Manajemen Bisnis, Vol. VI ,No. 2

Shantiuli, T. M., \& Said, S. (2014). Banking with the patron: a case study of patron-client relations in Makassar, Indonesia. Retrieved APril, 30, 2014.

Simamora, Henry. 2004. Manajemen Sumber Daya Manusia. Yogyakarta: STIE YKPN.

Sopiah. 2008. Perilaku Organisasional. Yogyakarta: Andi Offset.

Subyantoro, Arief. 2009. Karakteristik Individu, Karakteristik Pekerjaan, Karakteristik Organisasi dan Kepuasan Kerja Pengurus yang Dimediasi oleh Motivasi Kerja (Studi pada Pengurus KUD di Kabupaten Sleman), Jurnal Manajemen dan Kewirausahaan, Vol.11, No. 1, Maret, 11-19

Suhartini, Eka., \& Anisa, N. (2017). Pengaruh Kecerdasan Emosional Dan Kecerdasan Spiritual Terhadap Kinerja Perawat Rumah Sakit Daerah Labuang Baji Makassar. Jurnal Manajemen Ide dan Inspirasi, 4(01).

Sujana, Edy. 2012. Pengaruh Kompetensi, Motivasi, Kesesuaian Peran dan Komitmen Organisasi Terhadap Kinerja Auditor Internal Inspektorat Pemerintah Kabupaten (Studi pada Kantor Inspektorat Kabupaten Badung dan Buleleng), Jurnal Ilmiah Akuntansi dan Humanika, Volume 2, Nomor 1, Desember, 1-27

Susanty, Aries dan Sigit Wahyu Baskoro. 2012. Pengaruh Motivasi Kerja dan Gaya Kepemimpinan Terhadap Disiplin Kerja serta Dampaknya pada Kinerja Karyawan (Studi Kasus pada PT. PLN (Persero) APD Semarang), J@TI Undip, Vol VII, No 2, Mei, 77-84

Suwardi dan Joko Utomo. 2011. Pengaruh Motivasi Kerja, Kepuasan Kerja, dan Komitmen Organisasional Terhadap Kinerja Pegawai (Studi Pada Pegawai Setda Kabupaten Pati), Analisis Manajemen, Vol. 5 No. 1 Juli, 75-86 
Swietenia, Rita. 2009. Analisis Pengaruh Kepemimpinan, Kompensasi dan Karakteristik Pekerjaan Terhadap Disiplin Kerja Serta Implikasinya Terhadap Kinerja Pegawai (Studi Pada Kantor Pertanahan Kota Semarang). Jurnal Ekonomi - Manajemen-Akuntansi, No.6, Th. XVI, 96-116

Syariati, Alim \& Namla Elfa Syariati. 2012. Islamic Bank as Bank of Ethics. In Proceeding of Annual South East Asian International Seminar.

Sylvana, A., Si, M. and Murtiadi Awaluddin. (2017). Model Penciptaan Daya Saing Bisnis Melalui Transformasi Kewirausahaan Berbasis Tekhnologi Informasi (Technopreneur). Entrepreneurship at Global Crossroad: Challenges and Solutions, p.71.

Tobing, Diana Sulianti K. L. 2009. Pengaruh Komitmen Organisasional dan Kepuasan Kerja Terhadap Kinerja Karyawan PT. Perkebunan Nusantara III di Sumatera Utara, Jurnal Manajemen dan Kewirausahaan, Vol.11, No. 1, Maret 2009: 31-37

Veithzal, Rivai. 2005. Manajemen sumber daya manusia untuk perusahaan dari teori ke praktek .Jakarta : Grafindo Persada

Widodo, Untung. 2006. Analisis Pengaruh Gaya Kepemimpinan dan Kepuasan Kerja Terhadap Kinerja Bawahan (Studi Empiris Pada Perguruan Tinggi Swasta di Kota Semarang), Fokus Ekonomi, Vol. 1 No. 2 Desember, 92 - 108

Yahyo, Handoyo Djoko W dan Reni Shinta Dewi. 2013. Pengaruh Motivasi, Lingkungan Kerja, dan Kompensasi Terhadap Kinerja Karyawan Melalui Semangat Kerja Karyawan (Studi Kasus pada Karyawan Bagian Produksi CV. Putra Jaya Sahitaguna, Semarang), Diponegoro Journal of Social And Politic, 1-12 